\title{
Growth in a Time of Debt
}

\section{Citation}

Reinhart, Carmen M, and Kenneth S Rogoff. 2010. Growth in a time of debt. American Economic Review 100, no 2: 573-578.

\section{Published Version}

doi:10.1257/aer.100.2.573

\section{Permanent link}

http://nrs.harvard.edu/urn-3:HUL.InstRepos:11129154

\section{Terms of Use}

This article was downloaded from Harvard University's DASH repository, and is made available under the terms and conditions applicable to Other Posted Material, as set forth at http:// nrs.harvard.edu/urn-3:HUL.InstRepos:dash.current.terms-of-use\#LAA

\section{Share Your Story}

The Harvard community has made this article openly available.

Please share how this access benefits you. Submit a story.

Accessibility 


\title{
Growth in a Time of Debt
}

\author{
By Carmen M. Reinhart and Kenneth S. Rogoff ${ }^{*}$
}

In this paper, we exploit a new multi-country historical dataset on public (government) debt to search for a systemic relationship between high public debt levels, growth and inflation. Our main result is that whereas the link between growth and debt seems relatively weak at "normal" debt levels, median growth rates for countries with public debt over roughly 90 percent of GDP are about one percent lower than otherwise; average (mean) growth rates are several percent lower. Surprisingly, the relationship between public debt and growth is remarkably similar across emerging markets and advanced economies. This is not the case for inflation. We find no systematic relationship between high debt levels and inflation for advanced economies as a group (albeit with individual country exceptions including the United States). By contrast, in emerging market countries, high public debt levels coincide with higher inflation.

Our topic would seem to be a timely one. Public debt has been soaring in the wake of the recent global financial maelstrom, especially in the epicenter countries. This should not be surprising, given the experience of earlier severe financial crises. ${ }^{\text {Q }}$ Outsized deficits and epic bank bailouts may be useful in fighting a downturn, but what is the long-run macroeconomic impact,

* Reinhart: Department of Economics, 4115 Tydings Hall, University of Maryland, College Park, MD 20742 (e-mail: creinhar@umd.edu); Rogoff: Economics Department, 216 Littauer Center, Harvard University, Cambridge MA 02138-3001 (e-mail: krogoff@harvard.edu). The authors would like to thank Olivier Jeanne and Vincent R. Reinhart for helpful comments.

${ }^{1}$ In this paper "public debt" refers to gross central government debt. "Domestic public debt" is government debt issued under domestic legal jurisdiction. Public debt does not include debts carrying a government guarantee. Total gross external debt includes the external debts of all branches of government as well as private debt that is issued by domestic private entities under a foreign jurisdiction.

${ }^{2}$ Reinhart and Rogoff (2009a, b) demonstrate that the aftermath of a deep financial crisis typically involves a protracted period of macroeconomic adjustment, particularly in employment and housing prices. On average, public debt rose by more than 80 percent within three years after a crisis. especially against the backdrop of graying populations and rising social insurance costs? Are sharply elevated public debts ultimately a manageable policy challenge?

Our approach here is decidedly empirical, taking advantage of a broad new historical dataset on public debt (in particular, central government debt) first presented in Carmen $\mathrm{M}$. Reinhart and Kenneth S. Rogoff (2008, 2009b). Prior to this dataset, it was exceedingly difficult to get more than two or three decades of public debt data even for many rich countries, and virtually impossible for most emerging markets. Our results incorporate data on 44 countries spanning about 200 years. Taken together, the data incorporate over 3,700 annual observations covering a wide range of political systems, institutions, exchange rate and monetary arrangements, and historic circumstances.

We also employ more recent data on external debt, including debt owed both by governments and by private entities. For emerging markets, we find that there exists a significantly more severe threshold for total gross external debt (public and private) - which is almost exclusively denominated in a foreign currency - than for total public debt (the domestically issued component of which is largely denominated in home currency). When gross external debt reaches 60 percent of GDP, annual growth declines by about two percent; for levels of external debt in excess of 90 percent of GDP, growth rates are roughly cut in half. We are not in a position to calculate separate total external debt thresholds (as opposed to public debt thresholds) for advanced countries. The available time-series is too recent, beginning only in 2000. We do note, however, that external debt levels in advanced countries now average nearly 200 percent of GDP, with external debt levels being particularly high across Europe.

The focus of this paper is on the longer term macroeconomic implications of much higher public and external debt. The final section, however, summarizes the historical experience of the United States in dealing with private sector 


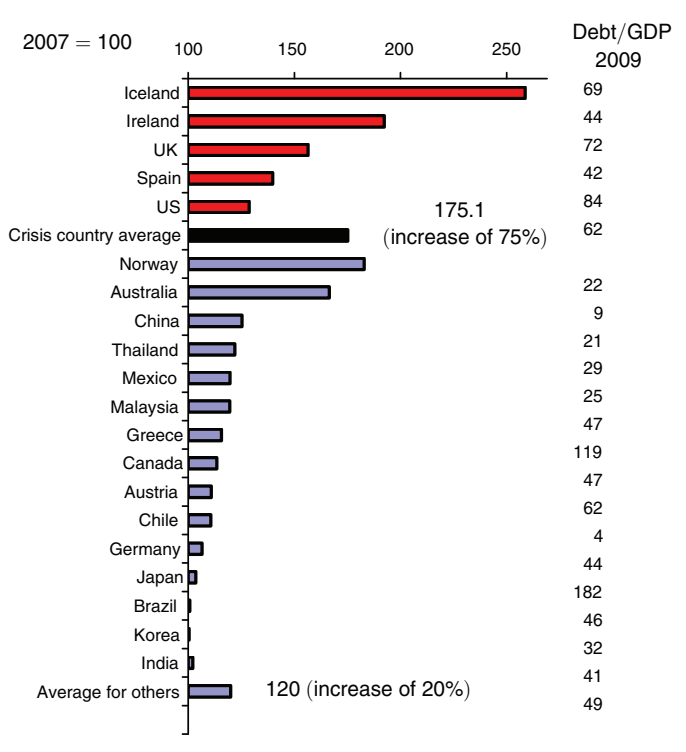

Figure 1. Cumulative Increase in Real Public Debt Since 2007, Selected Countries

Note: Unless otherwise noted these figures are for central government debt deflated by consumer prices.

Sources: Prices and nominal GDP from International Monetary Fund, World Economic Outlook. For a complete listing of sources for government debt, see Reinhart and Rogoff (2009b).

deleveraging of debts, normal after a financial crisis. Not surprisingly, such episodes are associated with very slow growth and deflation.

\section{The 2007-2009 Global Buildup in Public Debt}

Figure 1 illustrates the increase in (inflationadjusted) public debt that has occurred since 2007. For the five countries with systemic financial crises (Iceland, Ireland, Spain, the United Kingdom, and the United States), average debt levels are up by about 75 percent, well on track to reach or surpass the three year 86 percent benchmark that Reinhart and Rogoff (2009a,b), find for earlier deep postwar financial crises. Even in countries that did not experience a major financial crisis, debt rose by an average of about 20 percent in real terms between 2007 and 2009.

\footnotetext{
${ }^{3}$ Our focus on gross central government debt owes to the fact that time series of broader measures of government
}

This general rise in public indebtedness stands in stark contrast to the 2003-2006 period of public deleveraging in many countries and owes to direct bailout costs in some countries, the adoption of stimulus packages to deal with the global recession in many countries, and marked declines in government revenues that have hit advanced and emerging market economies alike.

\section{Debt, Growth, and Inflation}

The nonlinear effect of debt on growth is reminiscent of "debt intolerance" (Reinhart, Rogoff, and Miguel A. Savastano 2003) and presumably is related to a nonlinear response of market interest rates as countries reach debt tolerance limits. Sharply rising interest rates, in turn, force painful fiscal adjustment in the form of tax hikes and spending cuts, or, in some cases, outright default. As for inflation, an obvious connection stems from the fact that unanticipated high inflation can reduce the real cost of servicing the debt. Of course, the efficacy of the inflation channel is quite sensitive to the maturity structure of the debt. In principle, the manner in which debt builds up can be important. For example, war debts are arguably less problematic for future growth and inflation than large debts that are accumulated in peacetime. Postwar growth tends to be high as wartime allocation of manpower and resources funnels to the civilian economy. Moreover, high wartime government spending, typically the cause of the debt buildup, comes to a natural close as peace returns. In contrast, a peacetime debt explosion often reflects unstable political economy dynamics that can persist for very long periods.

Here we will not attempt to determine the genesis of debt buildups but instead simply look at their connection to average and median growth and inflation outcomes. This may lead us, if anything, to understate the adverse growth implications of debt burdens arising out of the current crisis, which was clearly a peacetime event.

debt are not available for many countries. Of course, the true run-up in debt is significantly larger than stated here, at least on a present value actuarial basis, due to the extensive government guarantees that have been conferred on the financial sector in the crisis countries and elsewhere, where for example deposit guarantees were raised in 2008. 


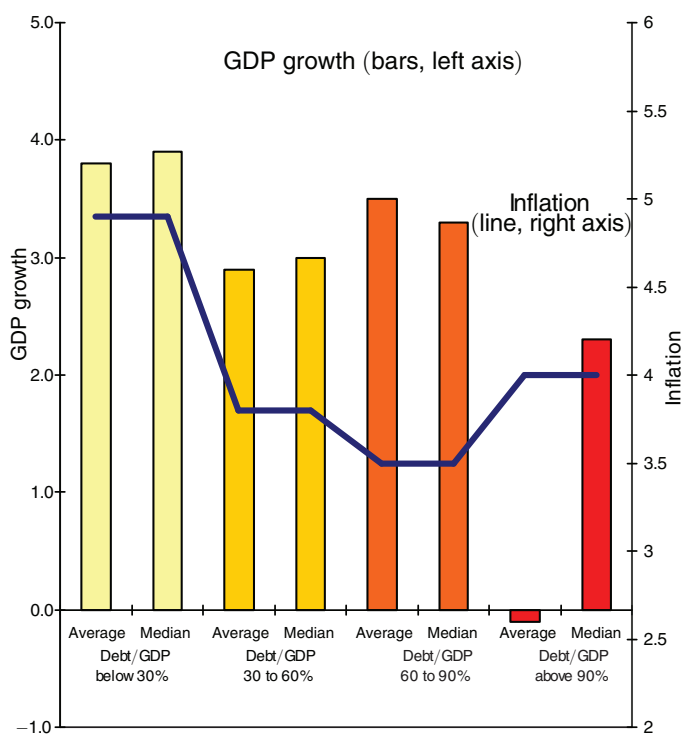

Figure 2. Government Debt, Growth, and Inflation: Selected Advanced Economies, 1946-2009

Notes: Central government debt includes domestic and external public debts. The 20 advanced economies included are Australia, Austria, Belgium, Canada, Denmark, Finland, France, Germany, Greece, Ireland, Italy, Japan, Netherlands, New Zealand, Norway, Portugal, Spain, Sweden, the United Kingdom, and the United States. The number of observations for the four debt groups are: 443 for debt/GDP below 30 percent; 442 for debt/GDP 30 to 60 percent; 199 observations for debt/GDP 60 to 90 percent; and 96 for debt/GDP above 90 percent. There are 1,180 observations.

Sources: International Monetary Fund, World Economic Outlook, OECD, World Bank, Global Development Finance, and Reinhart and Rogoff (2009b) and sources cited therein.

\section{A. Evidence from Advanced Countries}

Figure 2 presents a summary of inflation and GDP growth across varying levels of debt for 20 advanced countries over the period 1946-2009. This group includes Australia, Austria, Belgium, Canada, Denmark, Finland, France, Germany, Greece, Ireland, Italy, Japan, Netherlands, New Zealand, Norway, Portugal, Spain, Sweden, the United Kingdom, and the United States. The annual observations are grouped into four categories, according to the ratio of debt to GDP during that particular year as follows: years when debt to GDP levels were below 30 percent (low debt); years where debt/GDP was 30 to 60 percent (medium debt); 60 to 90 percent (high); and above 90 percent (very high). The bars in Figure 2 show average and median GDP growth for each of the four debt categories. Note that of the 1,186 annual observations, there are a significant number in each category, including 96 above 90 percent. (Recent observations in that top bracket come from Belgium, Greece, Italy, and Japan.) From the figure, it is evident that there is no obvious link between debt and growth until public debt reaches a threshold of 90 percent. The observations with debt to GDP over 90 percent have median growth roughly 1 percent lower than the lower debt burden groups and mean levels of growth almost 4 percent lower. (Using lagged debt does not dramatically change the picture.) The line in Figure 2 plots the median inflation for the different debt groupings - which makes plain that there is no apparent pattern of simultaneous rising inflation and debt.

Table 1 provides detail on the growth experience for individual countries, but over a much longer period, typically one to two centuries. Interestingly, introducing the longer time-series yields remarkably similar conclusions. Over the past two centuries, debt in excess of 90 percent has typically been associated with mean growth of 1.7 percent versus 3.7 percent when debt is low (under 30 percent of GDP), and compared with growth rates of over 3 percent for the two middle categories (debt between 30 and 90 percent of GDP). Of course, there is considerable variation across the countries, with some countries such as Australia and New Zealand experiencing no growth deterioration at very high debt levels. It is noteworthy, however, that those highgrowth high-debt observations are clustered in the years following World War II.

\section{B. Evidence from Emerging Market Countries}

We next perform the same exercise for 24 emerging market economies for the periods 1946-2009 and 1900-2009, using comparable central government debt data to those we used for the advanced economies. 1 Perhaps surprisingly, the results illustrated in Figure 2 and Table 1 for advanced economies are repeated for emerging market economies. The emerging

\footnotetext{
${ }^{4}$ While we have pre-1900 inflation, real GDP, and public debt data for many emerging markets, nominal GDP data is harder to find.
} 
Table 1-Real GDP Growth as the Level of Government Debt Varies:

Selected Advanced Economies, 1790-2009

(annual percent change)

\begin{tabular}{llcccc}
\hline \hline & & \multicolumn{3}{c}{ Central (federal) government debt/GDP } \\
\cline { 3 - 6 } Country & Period & $\begin{array}{c}\text { Below } 30 \\
\text { percent }\end{array}$ & $\begin{array}{c}30 \text { to } 60 \\
\text { percent }\end{array}$ & $\begin{array}{c}60 \text { to } 90 \\
\text { percent }\end{array}$ & $\begin{array}{c}90 \text { percent } \\
\text { and above }\end{array}$ \\
\hline Australia & $1902-2009$ & 3.1 & 4.1 & 2.3 & 4.6 \\
Austria & $1880-2009$ & 4.3 & 3.0 & 2.3 & n.a. \\
Belgium & $1835-2009$ & 3.0 & 2.6 & 2.1 & 3.3 \\
Canada & $1925-2009$ & 2.0 & 4.5 & 3.0 & 2.2 \\
Denmark & $1880-2009$ & 3.1 & 1.7 & 2.4 & n.a. \\
Finland & $1913-2009$ & 3.2 & 3.0 & 4.3 & 1.9 \\
France & $1880-2009$ & 4.9 & 2.7 & 2.8 & 2.3 \\
Germany & $1880-2009$ & 3.6 & 0.9 & n.a. & n.a. \\
Greece & $1884-2009$ & 4.0 & $\mathbf{0 . 3}$ & $\mathbf{4 . 8}$ & 2.5 \\
Ireland & $1949-2009$ & 4.4 & 4.5 & 4.0 & 2.4 \\
Italy & $1880-2009$ & $\mathbf{5 . 4}$ & $\mathbf{4 . 9}$ & 1.9 & 0.7 \\
Japan & $1885-2009$ & 4.9 & 3.7 & 3.9 & 0.7 \\
Netherlands & $1880-2009$ & 4.0 & 2.8 & 2.4 & 2.0 \\
New Zealand & $1932-2009$ & 2.5 & 2.9 & 3.9 & 3.6 \\
Norway & $1880-2009$ & 2.9 & 4.4 & n.a. & n.a. \\
Portugal & $1851-2009$ & 4.8 & 2.5 & 1.4 & n.a. \\
Spain & $1850-2009$ & $\mathbf{1 . 6}$ & 3.3 & $\mathbf{1 . 3}$ & 2.2 \\
Sweden & $1880-2009$ & 2.9 & 2.9 & 2.7 & n.a. \\
United Kingdom & $1830-2009$ & 2.5 & 2.2 & 2.1 & 1.8 \\
United States & $1790-2009$ & 4.0 & 3.4 & 3.3 & $-\mathbf{1 . 8}$ \\
Average & & $\mathbf{3 . 7}$ & $\mathbf{3 . 0}$ & $\mathbf{3 . 4}$ & $\mathbf{1 . 7}$ \\
Median & & $\mathbf{3 . 9}$ & $\mathbf{3 . 1}$ & $\mathbf{2 . 8}$ & $\mathbf{1 . 9}$ \\
Observations $=$ & $\mathbf{2 , 3 1 7}$ & 866 & 654 & 445 & 352 \\
\hline Nonyyyyy & & & & & \\
\hline
\end{tabular}

Notes: An n.a. denotes no observations were recorded for that particular debt range. There are missing observations, most notably during World War I and II years; further details are provided in the data appendices to Reinhart and Rogoff (2009b) and are available from the authors. Minimum and maximum values for each debt range are shown in bolded italics.

Sources: There are many sources; among the more prominent are: International Monetary Fund, World Economic Outlook, OECD, World Bank, Global Development Finance. Extensive other sources are cited in Reinhart and Rogoff (2009).

market equivalents of Figure 2 and Table 1 are not reproduced here (to economize on space), but the interested reader is referred to the NBER working paper version of this paper. For 1900-2009, for example, median and average GDP growth hovers around $4-4.5$ percent for levels of debt below 90 percent of GDP, but median growth falls markedly to 2.9 percent for high debt (above 90 percent); the decline is even greater for the average growth rate, which falls to 1 percent. With much faster population growth than the advanced economies', the implications for per capita GDP growth are in line (or worse) with those shown for advanced economies. The similarities with advanced economies end there, as higher debt levels are associated with significantly higher levels of inflation in emerging markets. Median inflation more than doubles (from less than seven percent to 16 percent) as debt rises from the low (0 to 30 percent) range to above 90 percent. Fiscal dominance is a plausible interpretation of this pattern.

Because emerging markets often depend so much on external borrowing, it is interesting to look separately at thresholds for external debt (public and private). In Figure 3, we highlight the connection between gross external debt as reported by the World Bank and growth and inflation. As one can see, the growth thresholds for external debt are considerably lower than the thresholds for total public debt. Growth deteriorates markedly at external debt levels over 


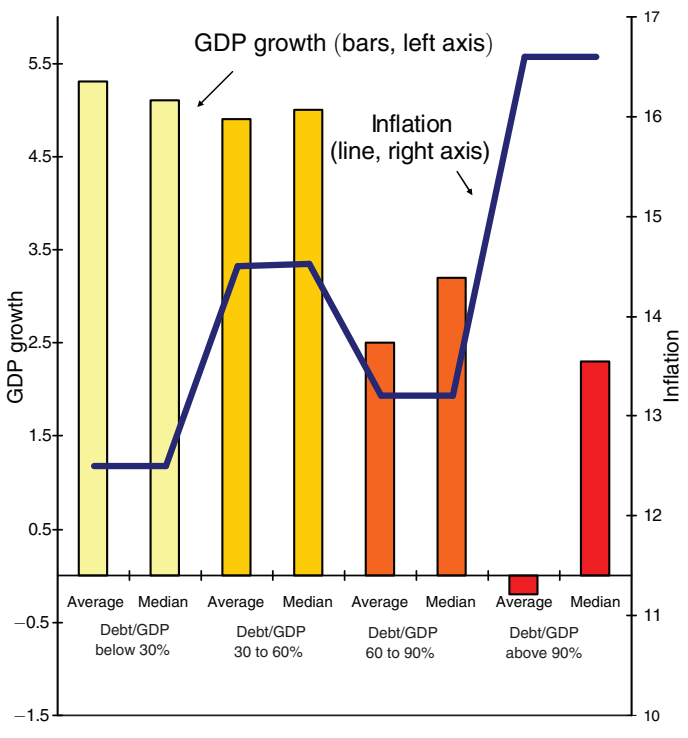

Figure 3. External Debt, Growth, and Inflation: Selected Emerging Markets, 1970-2009

Notes: The 20 emerging market countries included are Argentina, Bolivia, Brazil, Chile, China, Colombia, Egypt, India, Indonesia, Korea, Malaysia, Mexico, Nigeria, Peru, Philippines, South Africa, Thailand, Turkey, Uruguay, and Venezuela. The number of observations for the four debt groups are: 252 for debt/GDP below 30 percent; 309 for debt/GDP 30 to 60 percent; 120 observations for debt/GDP 60 to 90 percent; and 74 for debt/GDP above 90 percent. There is a total of 755 annual observations.

Sources: International Monetary Fund, World Economic Outlook, World Bank, Global Development Finance, and Reinhart and Rogoff (2009b) and sources cited therein.

60 percent, and further still when external debt levels exceed 90 percent, which record outright declines. In light of this, it is more understandable that over one half of all defaults on external debt in emerging markets since 1970 occurred at levels of debt that would have met the Maastricht criteria of 60 percent. Inflation becomes significantly higher only for the group of observations with external debt over 90 percent.

\section{Private Sector Debt: An Illustration}

Our main focus has been on central government debt and, to a lesser degree, external public and private debt, since reliable data on private domestic debts are much scarcer across countries and time. We have argued here and elsewhere that a key legacy of a deep financial crisis is rapidly expanding public debt. Furthermore, we have shown that public levels of debt/GDP that push the 90 percent threshold are associated with lower median and average growth. ${ }^{5}$ These observations, however, present only a partial picture of the post-financial crisis landscape. Private debt, in contrast, tends to shrink sharply in the aftermath of a financial crisis. Just as a rapid expansion in private credit fuels the boom phase of the cycle, so does serious deleveraging exacerbate the post-crisis downturn. This pattern is illustrated in Figure 4, which shows the ratio of private debt to GDP for the United States for 1916-2009. Periods of sharp deleveraging have followed periods of lower growth and coincide with higher unemployment. In varying degrees, the private sector (households and firms) in many other countries (notably both advanced and emerging Europe) are also unwinding the debt built up during the boom year. Thus, private deleveraging may be another legacy of the financial crisis that may dampen growth in the medium term.

\section{Concluding Remarks}

The sharp run-up in public sector debt will likely prove one of the most enduring legacies of the 2007-2009 financial crises in the United States and elsewhere. We examine the experience of 44 countries spanning up to two centuries of data on central government debt, inflation and growth. Our main finding is that across both advanced countries and emerging markets, high debt/GDP levels (90 percent and above) are associated with notably lower growth outcomes. Much lower levels of external debt/ GDP (60 percent) are associated with adverse outcomes for emerging market growth. Seldom do countries "grow" their way out of debts. The nonlinear response of growth to debt as debt grows towards historical boundaries is reminiscent of the "debt intolerance" phenomenon developed in Reinhart, Rogoff, and Savastano (2003). As countries hit debt tolerance ceilings, market interest rates can begin to rise quite suddenly, forcing painful adjustment.

Of course, there are other vulnerabilities associated with debt buildups, particularly if governments try to mitigate servicing costs by

\footnotetext{
${ }^{5}$ It is important to note that post-crises increases in public debt do not necessarily push economies into the vulnerable $90+$ debt/GDP range.
} 


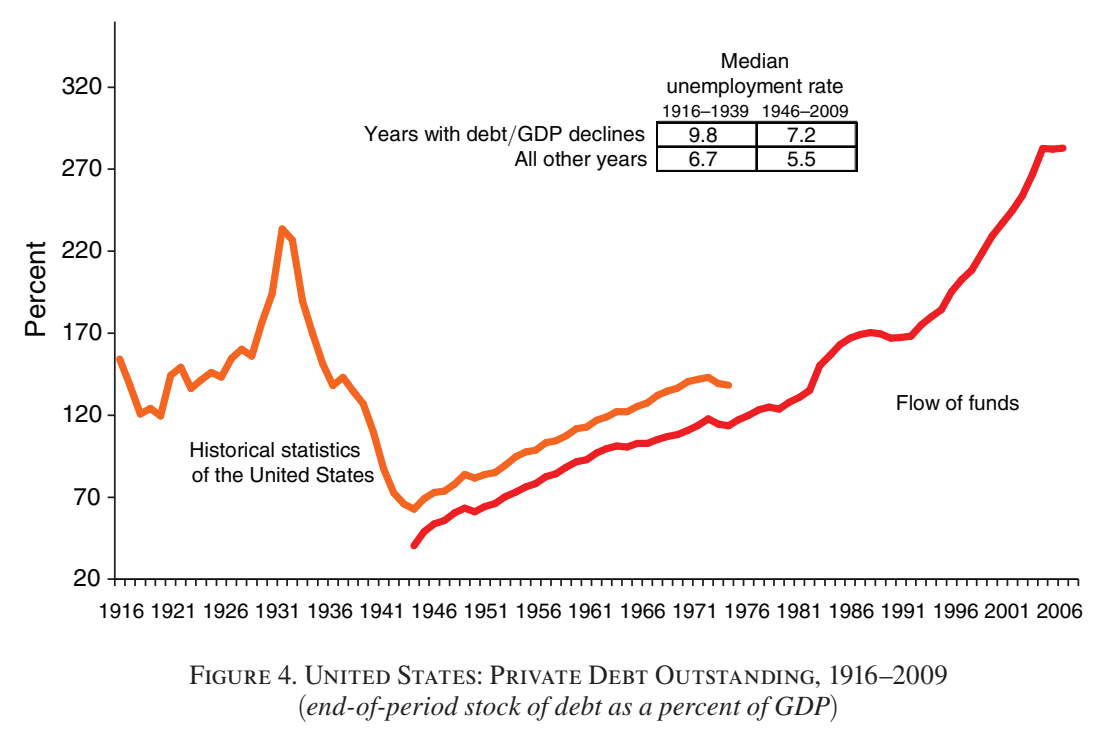

Note: Data for 2009 is end-of-June.

Sources: Historical Statistics of the United States, Flow of Funds, Board of Governors of the Federal Reserve, International Monetary Fund, World Economic Outlook, OECD, World Bank, Global Development Finance, and Reinhart and Rogoff (2009b) and sources cited therein.

shortening the maturing structure of debt. As Reinhart and Rogoff (2009b) emphasize and numerous models suggest, countries that choose to rely excessively on short-term borrowing to fund growing debt levels are particularly vulnerable to crises in confidence that can provoke very sudden and "unexpected" financial crises. At the very minimum, this would suggest that traditional debt management issues should be at the forefront of public policy concerns.

\section{REFERENCES}

Reinhart, Carmen M., and Kenneth S. Rogoff. 2008. "The Forgotten History of Domestic
Debt." National Bureau of Economic Research Working Paper 13946.

-Reinhart, Carmen M., and Kenneth S. Rogoff. 2009a. "The Aftermath of Financial Crises." American Economic Review, 99(2): 466-72.

Reinhart, Carmen M., and Kenneth S. Rogoff. 2009b. This Time Is Different: Eight Centuries of Financial Folly. Princeton, NJ: Princeton University Press.

Reinhart, Carmen M., Kenneth S. Rogoff, and Miguel A. Savastano. 2003. "Debt Intolerance." Brookings Papers on Economic Activity (1), ed. William C. Brainard and George L. Perry, 1-62. 


\section{This article has been cited by:}

1. Mike Taylor. 2014. Exploring the Boundaries: How Altmetrics Can Expand Our Vision of Scholarly Communication and Social Impact. Information Standards Quarterly 25:2, 27. [CrossRef]

2. Michael Jetter, Alex Nikolsko-Rzhevskyy, William T. Smith. 2013. The effects of wage volatility on growth. Journal of Macroeconomics 37, 93-109. [CrossRef]

3. Pedro Leão. 2013. The Effect of Government Spending on the Debt-to-GDP Ratio: Some Keynesian Arithmetic. Metroeconomica 64:3, 448-465. [CrossRef]

4. Yacouba Gnegne, Fredj Jawadi. 2013. Boundedness and nonlinearities in public debt dynamics: A TAR assessment. Economic Modelling . [CrossRef]

5. Dzmitry Kruk. 2013. Belarus' Anti-Crisis Management: Success Story of Delayed Recession?. EuropeAsia Studies 65:3, 473-488. [CrossRef]

6. Radu Vranceanu, Damien Besancenot. 2013. The spending multiplier in a time of massive public debt: The Euro-area case. Applied Economics Letters 20:8, 758-762. [CrossRef]

7. W. Robert J. Alexander. 2013. THE DEFENCE-DEBT NEXUS: EVIDENCE FROM THE HIGH-INCOME MEMBERS OF NATO. Defence and Peace Economics 24:2, 133-145. [CrossRef]

8. N. Bilkic, B. Carreras Painter, T. Gries. 2013. Unsustainable sovereign debt-is the Euro crisis only the tip of the iceberg?. International Economics and Economic Policy 10:1, 1-45. [CrossRef]

9. MASSIMO ANTONINI, KEVIN LEE, JACINTA PIRES. 2013. Public Sector Debt Dynamics: The Persistence and Sources of Shocks to Debt in 10 EU Countries. Journal of Money, Credit and Banking 45:2-3, 277-298. [CrossRef]

10. Miklós Antal, Jeroen C.J.M. van den Bergh. 2013. Macroeconomics, financial crisis and the environment: Strategies for a sustainability transition. Environmental Innovation and Societal Transitions 6, 47-66. [CrossRef]

11. Atish R. Ghosh, Jun I. Kim, Enrique G. Mendoza, Jonathan D. Ostry, Mahvash S. Qureshi. 2013. Fiscal Fatigue, Fiscal Space and Debt Sustainability in Advanced Economies. The Economic Journal 123:566, F4-F30. [CrossRef]

12. António Afonso, João Tovar Jalles. 2013. Growth and productivity: The role of government debt. International Review of Economics \& Finance 25, 384-407. [CrossRef]

13. Moritz Schularick. 2012. Public debt and financial crises in the twentieth century. European Review of History: Revue europeenne d'bistoire 19:6, 881-897. [CrossRef]

14. Cosimo Magazzino. 2012. Wagner versus Keynes: Public spending and national income in Italy. Journal of Policy Modeling 34:6, 890-905. [CrossRef]

15. Kruti Dholakia-Lehenbauer, Euel Elliott, Bruce Cordell. 2012. Economic rhythms, Maslow Windows and the new space frontier. Space Policy 28:4, 291-298. [CrossRef]

16. S. Dieckmann, T. Plank. 2012. Default Risk of Advanced Economies: An Empirical Analysis of Credit Default Swaps during the Financial Crisis. Review of Finance 16:4, 903-934. [CrossRef]

17. Huiran Pan, Chun Wang. 2012. Co-movement of Government Debt and Economic Growth in the Euro-area: A Bayesian Dynamic Factor Model Analysis. International Economic Journal 1-19. [CrossRef]

18. Andrea F Presbitero. 2012. Total Public Debt and Growth in Developing Countries. European Journal of Development Research 24:4, 606-626. [CrossRef]

19. Philip R. Lane. 2012. The European Sovereign Debt Crisis. Journal of Economic Perspectives 26:3, 49-68. [Abstract] [View PDF article] [PDF with links] 
20. Emanuele Baldacci, Sanjeev Gupta, Carlos Mulas-Granados. 2012. Reassessing the fiscal mix for successful debt reduction. Economic Policy 27:71, 365-406. [CrossRef]

21. 2012. Book Reviews. Journal of Economic Literature 50:2, 513-546. [Citation] [View PDF article] [PDF with links]

22. 2012. Book Reviews. Journal of Economic Literature 50:2, 525-527. [Abstract] [View PDF article] [PDF with links]

23. 2012. Book Reviews. Journal of Economic Literature 50:2, 527-529. [Abstract] [View PDF article] [PDF with links]

24. Davide Furceri, Aleksandra Zdzienicka. 2012. How costly are debt crises?. Journal of International Money and Finance 31:4, 726-742. [CrossRef]

25. L. Taylor, C. R. Proano, L. de Carvalho, N. Barbosa. 2012. Fiscal deficits, economic growth and government debt in the USA. Cambridge Journal of Economics 36:1, 189-204. [CrossRef]

26. Michael Beckley. 2012. China's Century? Why America's Edge Will Endure. International Security 36:3, 41-78. [CrossRef]

27. P. Halmai, V. Vásáry. 2011. Crisis and economic growth in the EU. Acta Oeconomica 61:4, 465-485. [CrossRef]

28. Marcel Fratzscher, Arnaud Mehl, Isabel Vansteenkiste. 2011. 130 Years of Fiscal Vulnerabilities and Currency Crashes in Advanced Economies. IMF Economic Review 59:4, 683-716. [CrossRef]

29. Yochanan Shachmurove. 2011. A historical overview of financial crises in the United States. Global Finance Journal . [CrossRef]

30. Carmen M. Reinhart,, Kenneth S. Rogoff. 2011. From Financial Crash to Debt Crisis. American Economic Review 101:5, 1676-1706. [Abstract] [View PDF article] [PDF with links]

31. Shiyu Li, Shuanglin Lin. 2011. The size and structure of China's government debt. The Social Science Journal . [CrossRef]

32. Antoine Parent. 2011. A critical note on "This time is different". Cliometrica . [CrossRef]

33. Geoffrey Meen. 2011. The economic consequences of mortgage debt. Journal of Housing and the Built Environment . [CrossRef]

34. Joshua Aizenman, Yothin Jinjarak. 2011. The Fiscal Stimulus of 2009-2010: Trade Openness, Fiscal Space, and Exchange Rate Adjustment. NBER International Seminar on Macroeconomics 8:1, 301-342. [CrossRef]

35. Paul J. J. Welfens. 2011. From the transatlantic banking crisis to the euro crisis?. International Economics and Economic Policy . [CrossRef]

36. Yeva Nersisyan, L. Randall Wray. 2011. Review. Challenge 54:1, 113-120. [CrossRef]

37. Dongchul Cho, Sukha Shin. 2011. Time to shift from macro- to micro-policies. Journal of Policy Analysis and Management $\mathrm{n} / \mathrm{a}-\mathrm{n} / \mathrm{a}$. [CrossRef] 